Historic, archived document

Do not assume content reflects current scientific knowledge, policies, or practices. 

Forest Service

Pacific Northwest

Forest and Range

Experiment Station

Research Note

PNW-375

March 1981

\section{Checklist of the Vascular Plants of Steamboat Mountain Research Natural Area}

\author{
S. Reid Schuller and Robert E. Frenkel
}

\section{Abstract}

\section{Environment}

Lists 237 vascular plant taxa found in the 570-hectare Steamboat Mountain Research Natural Area. Notes on habitats, community types, and abundance are included for most taxa.

Keywords: Vascular plants, checklists (vascular plants), natural areas (research), Washington (Steamboat Mountain Research Natural Area).

This research note provides scientists, educators, and land managers with baseline information on the presence, location, and abundance of vascular plants within the Steamboat Mountain Research Natural Area. In the future, changes in the vegetation--additions, deletions, changes in abundance, and shifts in habitat--can be determined from this baseline. The checklist can also be used in evaluating the effects of human activities in equivalent ecosystem types.

Steamboat Mountain Research Natural Area occupies 570 hectares on the north and south slopes of Steamboat Mountain in the Gifford Pinchot National Forest in the southern Washington Cascades. This Research Natural Area, administered by the Mount Adams Ranger District, was established in 1974 to fill four natural area needs in the Pacific Silver Fir and Mountain Hemlock Zones: (1) Pacific silver fir forest, southern portion of the Western Cascades physiographic province; (2) mountain hemlock-Pacific silver fir forest, southern portion; (3) typical subalpine fir forest; and (4) marsh and bog ecosystems (Dyrness et al. 1975).
S. REID SCHULLER is with the Wa shington Natural Heritage Program, The Nature Conservancy; and ROBERT E. FRENKEL is with the Department of Geography, Oregon State University. The work reported was done under a contract with the Pacific Northwest Forest and Range Experiment Station and the Pacific Northwest Natura 1 Area Committee. 
Habitats and Plant Community Types
Steamboat Mountain exhibits a strongly developed gradient in forest composition across contrasting southwest and steep north slopes. Substantial areas of special habitat are present, including: talus, rock outcrop, wet meadow, bog, willow carr, and small pond. Elevations range from 1190 meters $(3,900 \mathrm{ft})$ at the western edge to 1654 meters $(5,300 \mathrm{ft}$ ) at the summit. Topography is generally steep ( 30 to 60 percent), except for the gentle, broad southwest lower slope and the cliffs north and east of the summit ridge. Steamboat Mountain is predominantly underlain by Miocene basaltic rocks, with Eocene-Oligocene volcanics being more common at lower elevations in the western portion of the area. Soils are mostly Spodosols, developed on Pleistocene to Recent aeolian ash and pumice deposits. The climate is wet and cold in winter; average snowpack varies from 200 to 300 centimeters ( 79 to 118 inches) at the time of maximum accumulation in early April.

Eight major habitats and their plant community types were identified and mapped at Steamboat Mountain-Research Natural Area by Franklin.l Since plant taxa in this checklist are related to these habitats and community types (units), the habitats and seven plant community types (clearcuts not included) are briefly described below. Figure 1 shows the distribution of each unit.

Inpublished "Establishment Report, Steamboat Mountain Research Natural Area, Gifford Pinchot National Forest," on file at Forestry Sciences Laboratory, Corvallis, Oregon. 
Abies lasiocarpa - ABLA

Abies amabilis-Tsuga mertensiana - TSME

Abies amabilis-Tsuga mertensiana.Picea engelmannii-PIEN

$\because \because$ Abies amabilis-ABAM

$\therefore$ Mixed conifer IPseudolsuga menziesii-Abies procera.Tsuga mertensiana)-PSME

Clearcuts

Meadows and marshes-WET

Cliffs and scree slopes-ROCK

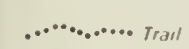

$\mathbf{0} \mathbf{m} \mathbf{m}$ Roud

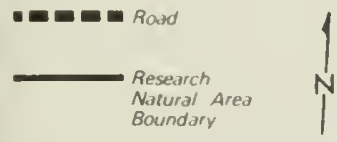

123 Ravi
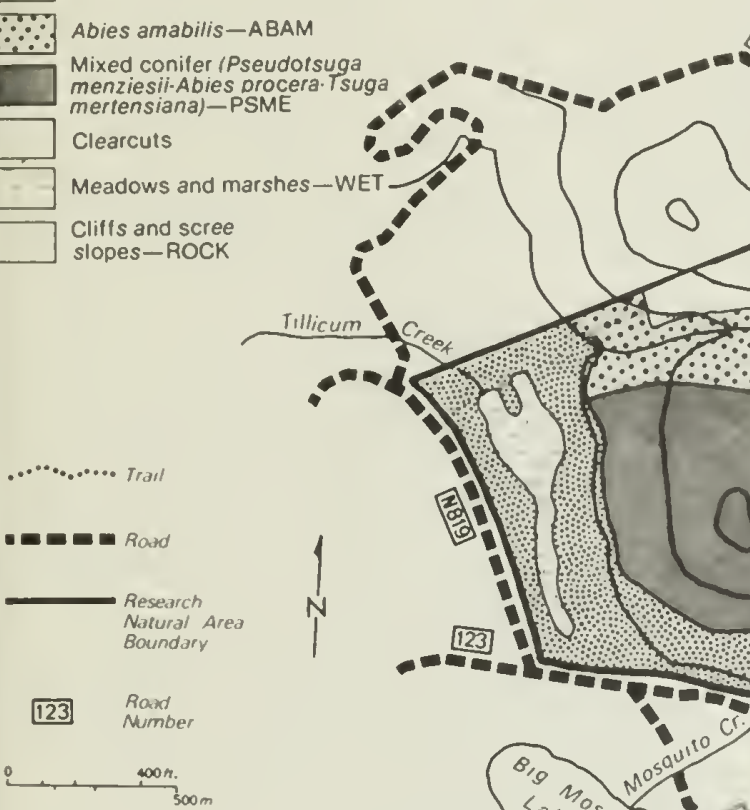

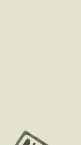
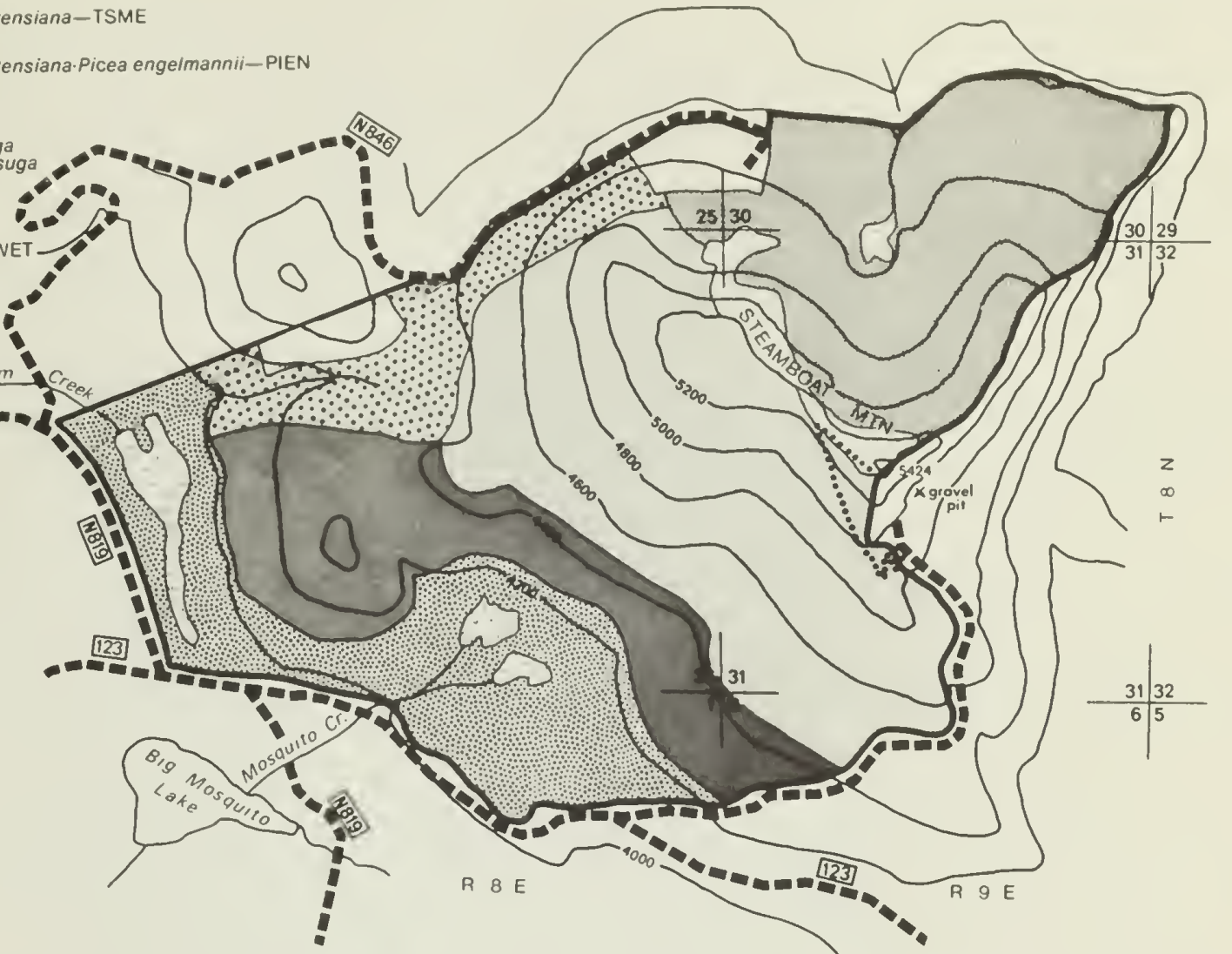

R $8 E$
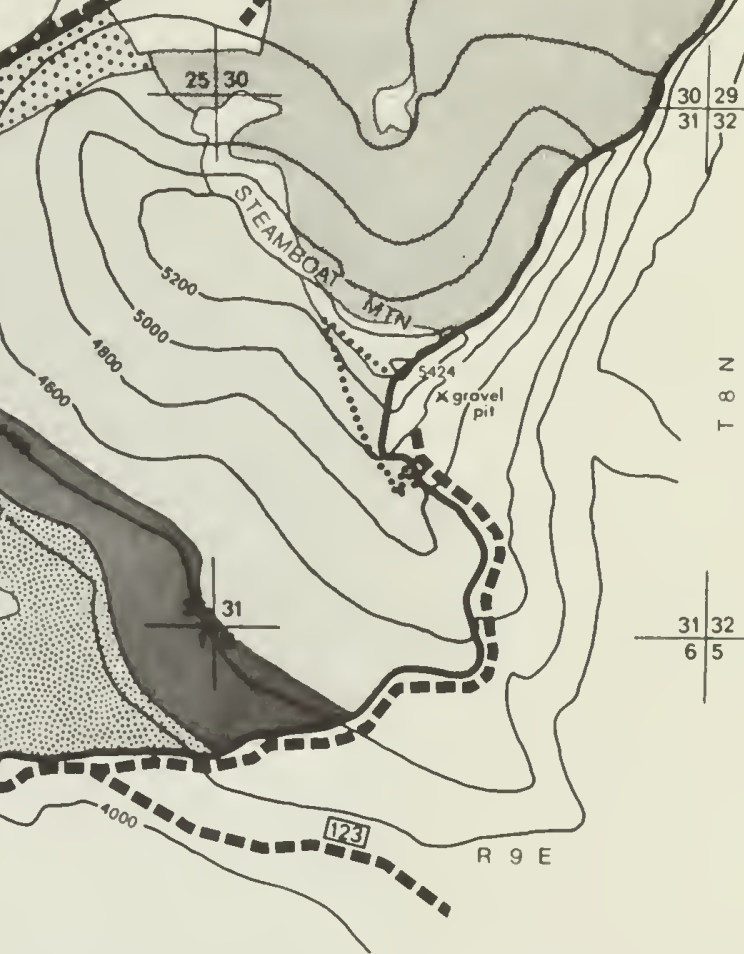

Figure 1.--Major habitats and community types in Steamboat Mountain Research Natural Area, Gifford Pinchot National Forest, Washington.

Abies lasiocarpa Forest

Found on the upper two-thirds of the southwest slope of Steamboat Mountain, the forest is dominated by an Abies lasiocarpa/Vaccinium membranaceum/Xerophyllum tenax plant community that includes substantial Abies amabilis and Tsuga mertensiana. Typical understory species are Rubus lasiococcus, Pyrola secunda, Bromus vulgaris, and Nothochelone nemorosa.

Abies amabilis-

Tsuga mertensiana Forest
Dominating the cool, north steep-to-gentle slopes of Steamboat Mountain, this unit contains an Abies amabilis-Tsuga mertensiana/Rhododendron albiflorum-Vaccinium plant community. Besides the widespread Vaccinium membranaceum, V. ovalifolium is an important shrub. Rubus lasiococcus, R. pedatus, Clintonia uniflora, and Smilacina stellata are common plants in the herb layer. 
Abies amabilis-

Tsuga mertensiana-

Picea engelmannii Forest

Abies amabilis Forest

Pseudotsuga menziesiiAbies procera.

Tsuga mertensiana Forest

\section{Clearcuts}

Meadows and Marshes

Cliffs and Scree Slopes

\section{Explanation and \\ Arrangement \\ of Checklist}

Surrounding the open wetlands at the south and west fringe of the natural area is a moist forest dominated by an Abies amabilis-Picea engelmannii-Tsuga mertensiana/Vaccinium membranaceum community. Like the Abies lasiocarpa forest, it is considered a successional type. A floristically rich herbaceous understory prevails.

Fringing the northwest margin of the natural area is a relatively homogeneous Abies amabilis forest with Vaccinium membranaceum dominating the understory. This type is closely related to the Pacific silver fir-mountain hemlock forest.

Found in a narrow band at the base of the southwest slope, this dry-site successional type includes a Pseudotsuga menziesi-Abies procera/Abies amabilis/Vaccinium membranaceum plant community and is considered successional to the Abies amabilis-Tsuga heterophylla/Achlys triphylla climax association.

Two small clearcuts covering 18 hectares along the north margin of the natural area were not included in this survey.

Four areas of wetland occupying 19 hectares are found in the southwest and northwest portions of the natural area. Three large bogs (montane mires) have patches of willow carr, areas of Sphagnum, extensive carpets of Vaccinium occidentale, and Carex spp. These open wetlands are among the most

floristically rich vegetation types on Steamboat Mountain. A small lake, due north of the summit, is included in the wetland type.

This unit occupies a narrow strip along the summit; cliffs and associated scree are along the north slope. The variety of microhabitats in this type account for the floristic richness encountered, especially where soil has accumulated.

The list includes all vascular plant taxa identified in the Steamboat Mountain Research Natural Area during field visits on June 18; July 2, 3, and 29; and August 8, 11, and 19, 1979. A few taxa are included that were not sighted in 1979 but were recorded earlier in field notes. Plants in clearcuts and within 10 meters $(32 \mathrm{ft}$ ) of roads were not listed unless they occurred elsewhere in the Research Natural Area.

Taxa for which no collection numbers are listed were identified in the field by the authors. Collections were verified in the herbaria at the University of Washington, Seattle, and at Oregon State University, Corvallis. Vouchers are deposited at the University of Washington, Seattle.

Families, genera, and species are arranged alphabetically. Scientific nomenclature and taxonomy follow Hitchcock and Cronquist (1973); common names are from Franklin and Dyrness (1973); additional floristic references include Hitchcock et al. $(1955-69)$. 
Habitats and plant community types in which a given taxon occurs are indicated by symbols in the checklist:

ABLA--Abies lasiocarpa forest TSME--Abies amabilis-Tsuga mertensiana forest PIEN--Abies amabilis-Tsuga mertensiana-Picea engelmannii forest ABAM--Abies amabilis forest

PSME--Pseudotsuga menziesii-Abies procera-Tsuga mertensiana forest WET --meadows and marshes ROCK--cliffs and scree slopes

In many cases, a given taxon appears among many plant community types, and we have attempted to identify only its major distribution. Species abundance was qualitatively estimated in the field and is recorded as infrequent, occasional, frequent, or abundant.

Araceae

Araliaceae

Berberidaceae

Betulaceae

Boraginaceae

Campanulaceae

Caprifoliaceae
Lysichitum americanum Hultén \& St. John, skunkcabbage-occasional in WET and in moist areas in PIEN, ABAM, and PSME.

Oplopanax horridum (Smith) Miq., devil's club--occasional in ABAM and along streams in PIEN.

Achlys triphylla (Smith) DC., deerfoot vanillaleaf--occasional in PIEN, ABAM, and TSME.

Vancouveria hexandra (Hook.) Moor. \& Dec., white inside-out flower--infrequent in moist areas in PIEN and PSME.

Alnus sinuata (Regel) Rydb., Sitka alder--frequent in WET and in talus in ROCK (S816).2

Mertensia paniculata (Ait.) G. Don var. borealis (Macbr.) Williams, smooth panicle bluebells--infrequent to occasional in $A B L A$, frequent in talus in ROCK (S826).

Campanula rotundifolia L., American harebell--infrequent to occasional in ROCK.

Linnaea borealis L., western twinflower--occasional in ABAM.

Lonicera caerulea L., blue fly honeysuckle--infrequent in WET.

Sambucus racemosa L. var. arborescens (T. \& G.) Gray, red elderberry--infrequent in WET.

Viburnum edule (Michx.) Raf., high-bush cranberry--occasional in WET, infrequent along streams in PIEN.

${ }^{2}$ Letters and numbers in parentheses after a listing are collection numbers. 
Caryophyllaceae

Celastraceae

Compositae (Asteraceae)
Arenaria capillaris Poir. var. americana (Mag.) Davis, fescue sandwort--frequent in ROCK (F2674).

Arenaria macrophylla Hook., bigleaf sandwort--occasional in PIEN, ABAM, and ABLA.

Silene parryi (Wats.) Hitchc. \& Mag., Parrys silene--frequent in ROCK ( $\underline{\mathrm{S} 878})$.

Pachistima myrsinites (Pursh) Raf., Oregon boxwood--frequent in ABLA, occasional in ROCK and ABAM.

Achillea millefolium L. ssp. lanulosa (Nutt.) Piper, western yarrow--infrequent in ROCK and WET.

Agoseris aurantiaca (Hook.) Greene, orange agoseris--infrequent in ROCK.

Anaphalis margaritacea (L.) B. \& H., pearly everlasting-infrequent in ROCK.

Antennaria microphylla Rydb., rosy pussy-toes--infrequent in ROCK (S868).

Arnica latifolia Bong. var. gracilis (Rydb.) Cronq., broadleaf arnica--collected in ABLA (S842).

Arnica latifolia Bong. var. latifolia, broadleaf arnica-infrequent in ABLA and TSME.

Arnica mollis Hook., hairy arnica--infrequent in ABLA and TSME (S

Artemisia ludoviciana Nutt. var. latiloba Nutt., western wormwood--infrequent in ROCK (S877).

Aster foliaceus Lindl. var. parryi (Eat.) Gray, Parry's leafy aster--occasional in WET (S817).

Aster ledophyllus Gray, Cascades aster--occasional in ROCK (S809).

Aster modestus Lindl., fewflower aster--occasional in WET (F2728).

Erigeron acris L. var. debilis Gray, dwarf mountain fleabane--

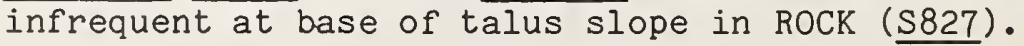

Erigeron compositus Pursh var. glabratus Macoun, dwarf mountain fleabane--infrequent in ROCK. 
Cornaceae

Crassulaceae

Cruciferae (Brassicaceae)

Cupressaceae

Cyperaceae
Erigeron peregrinus (Pursh) Greene ssp. callianthemus (Greene) Cronq. var. scaposus ( $T$. \& G.) Cronq., peregrine fleabane-collected in ROCK.

Hieracium albiflorum Hook., white hawkweed--frequent in ABLA, occasional in TSME and ABAM, infrequent in PSME and PIEN.

Hieracium cynoglossoides Arv.-Touv., houndstongue hawkweed-infrequent in ROCK (S814).

Petasites frigidus (L.) Fries var. palmatus (Ait.) Cronq., coltsfoot--infrequent in WET.

Senecio cymbalarioides Buek, few-leaved groundsel--occasional in WET; infrequent in moist areas of PIEN, ABAM, PSME, and ABLA (S864).

Senecio integerrimus Nutt. var. exaltatus (Nutt.) Cronq., tall western groundsel--collected in ABLA.

Senecio triangularis Hook., arrowleaf groundsel--occasional in WET; infrequent to occasional in moist areas in ABAM, PIEN, TSME, PSME, and ABLA.

Cornus canadensis L., bunchberry dogwood--occasional in WET and PIEN.

Cornus stolonifera Michx., red-osier dogwood--infrequent at edge of WET, occasional along streams in PIEN.

Sedum divergens Wats., spreading stonecrop--frequent in $\overline{\text { ROCK }}$ ( $\underline{\text { S880 }}$ ).

Arabis furcata Wats., fork-haired rockcress--infrequent in ABLA, occasional in ROCK (F2675).

Juniperus communis L. var. montana Ait., common mountain juniper-occasional in ROCK.

Thuja plicata Donn., western redcedar--occasional in PIEN, infrequent in ABAM.

Carex aquatilis Wahl., water sedge--occasional in WET (S822).

Carex canescens Bailey, gray sedge--infrequent in WET (S885).

Carex cusickii Mack., Cusick's sedge--occasional to frequent in WET (S824).

Carex laeviculmis Meinsch., smooth-stem sedge--infrequent along outer margins of WET (S886). 
Carex lenticularis Michx., Kellogg's sedge--infrequent to frequent in WET ( $\underline{S 833})$.

Carex limnophila Hermann, pondsedge--infrequent to occasional in open ABLA and in PIEN (

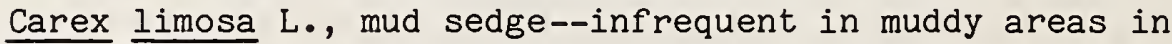
WET (S887).

Carex luzulina Olney, luzula-like sedge--occasional in WET.

Carex mertensii Prescott, Mertens sedge--collected along creek in $A B A M(\underline{S 889})$.

Carex muricata L., western stellate sedge--occasional along outer margins of WET (S818).

Carex neurophora Mack., alpine nerved sedge--collected in WET (S821).

Carex pachystachya Cham. ex Steud., thick-headed sedge-collected in ABLA (S882).

Carex pensylvanica Lam. var. vespertina L. H. Bailey, long-stoloned sedge--occasional in ABLA and ROCK (S890).

Carex rossii Boott, Ross sedge--infrequent in PIEN and ABAM, frequent in ROCK (S891).

Carex rostrata Stokes ex With., beaked sedge--occasional to abundant in WET (S892).

Carex sitchensis Prescott, Sitka sedge--frequent in WET (S884).

Eleocharis pauciflora (Lightf.) Link, few-flowered spikesedge-occasional in WET.

Eriophorum polystachion L., tall cotton-grass--frequent in WET.

Scirpus microcarpus Presl, small-fruited bulrush--occasional in riparian habitats in PIEN, ABAM, and PSME; frequent along outer margins of WET (F2673).

Drosera anglica Huds., great sundew--infrequent to occasional in WET ( 
Equisetum fluvialtile L., water horsetail--occasional in WET $(\underline{\text { S8II }})$.

Equisetum sp., horsetail--sighted in ROCK.

Arctostaphylos nevadensis Gray, pine-mat manzanita--infrequent in ROCK.

Chimaphila menziesii (R. Br.) Spreng., little prince's pine-infrequent in TSME, PIEN, ABAM, and PSME.

Chimaphila umbellata (L.) Bart. var. occidentalis (Rydb.) Blake, western prince's pine--occasional in ABLA, TSME, and PIEN.

Gaultheria humifusa (Grah.) Rydb., western wintergreen--rare in PIEN and PSME.

Kalmia microphylla (Hook.) Heller, alpine laurel or kalmia-infrequent in WET.

Kalmia occidentalis Small, bog laurel or kalmia--infrequent to occasional in WET.

Menziesia ferruginea Smith, fool's huckleberry or rustyleaf-frequent in ABAM, TSME, and PSME; infrequent in PIEN and ABLA; infrequent in ROCK.

Monotropa uniflora L., indianpipe--not sighted in 1979 but previously reported in field notes.

Phyllodoce empetriformis (Sw.) D. Don, red mountainheather-abundant in ROCK.

Pyrola asarifolia Michx., large pyrola--infrequent along creeks in PIEN and PSME.

Pyrola chlorantha Sw., green pyrola--rare in PIEN.

Pyrola minor L., snowline pyrola--infrequent in TSME, PIEN, and ABAM.

Pyrola picta Smith, whitevein pyrola--rare in ABAM.

Pyrola secunda L., one-sided wintergreen--occasional in TSME, PIEN, ABAM, and ABLA.

Rhododendron albiflorum Hook., Cascades azalea--occasional in ROCK.

Vaccinium caespitosum Michx., dwarf huckleberry--occasional in WET. 
Vaccinium deliciosum Piper, blueleaf huckleberry--infrequent in WET.

Vaccinium membranaceum Dougl., big huckleberry--abundant in ABLA and TSME; frequent in ABAM, PIEN, and PSME; infrequent in WET and ROCK.

Vaccinium occidentale Gray, westernbog huckleberry--abundant in WET $(\underline{S 833})$.

Vaccinium ovalifolium Smith, ovalleaf huckleberry--frequent in PIEN, ABAM, and PSME; occasional in TSME.

Vaccinium oxycoccus L., wild or swamp cranberry--occasional to frequent in WET.

Vaccinium scoparium Leiberg, grouse huckleberry--occasional in TSME and ABLA, frequent at base of talus slope in ROCK.

Agrostis alba L., redtop--collected in ROCK (F2761).

Agrostis exarata Trin., spike bentgrass--collected in moist seep in PIEN (F2749).

Agrostis idahoensis Nash, Idaho bentgrass--collected in WET (F2714).

Agrostis scabra Willd., winter bentgrass--collected in WET (F2727).

Agrostis thurberiana Hitchc., Thurber's bentgrass--collected in WET (

Agrostis variabilis Rydb., variant bentgrass--collected in ROCK ( $\underline{F 2754)}$.

Bromus pacificus Shear, Pacific brome--collected in ROCK (F2756).

Bromus suksdorfii Vasey, Suksdorf's brome--collected in ABLA (F2738).

Bromus vulgaris (Hook.) Shear, Columbia brome--frequent in ABLA, occasional in ROCK and WET (F274I).

Calamagrostis canadensis (Michx.) Beauv., bluejoint reedgrass-occasional in moist areas in ABLA and WET (S519).

Calamagrostis inexpansa Gray, narrow-spiked reedgrass--collected in ROCK (F2763). 
Danthonia intermedia Vasey, timber danthonia--collected at base of talus slope in ROCK (S518).

Deschampsia cespitosa (L.) Beauv., tufted hairgrass--occasional in WET.

Elymus glaucus Buckl., blue wildrye--occasional in ABLA and ROCK ( $\underline{F 2735)}$.

Festuca idahoensis Elmer var. idahoensis, Idaho fescue-collected in ROCK ( $\underline{\text { F2803 }}$ ).

Festuca idahoensis Elmer var. oregona (Hack.) Hitchc., Idaho fescue--collected in ROCK (F2769).

Festuca subulata Trin., bearded fescue--collected in ABLA (F2737).

Glyceria elata (Nash) Jones, tall mannagrass--frequent in WET $(\underline{F 2747)}$.

Muhlenbergia filiformis (Thurb.) Rydb., pullup muhly--collected in WET (F2722).

Phleum alpinum L., alpine timothy--infrequent in WET.

Phleum pratense L., timothy--collected in ROCK (F2760).

Poa sandbergii Vasey, Sandberg's bluegrass--collected in ROCK (F2772).

Puccinellia pauciflora (Presl) Munz, weak alkaligrass-collected in WET (F2748).

Sitanion hystrix (Nutt.) Smith, bottlebrush squirreltail-collected in ROCK (

Stipa occidentalis Thurb., western needlegrass--collected in ROCK (

Trisetum spicatum (L.) Richter, downy oatgrass--infrequent in PIEN, ABLA, and ROCK (F2742).

Ribes bracteosum Dougl., stink currant--infrequent in moist areas in PIEN and ABAM.

Ribes howellii Greene, mapleleaf currant--collected in ROCK $(\underline{\text { S839) }}$. 
Ribes lacustre (Pers.) Poir., prickly currant--infrequent in WET, occasional in moist areas in PIEN.

Ribes viscosissimum Pursh, sticky currant--collected in ROCK.

Hydrophyllaceae

Hypericaceae

Juncaceae

Labiatae (Lamiaceae)

Leguminosae (Fabaceae)
Phacelia hastasta Dougl. var. leptosepala (Rydb.) Cronq., whiteleaf phacelia--occasional in ABLA.

Hypericum anagalloides C. \& S., bog St. Johnswort--occasional to frequent in WET.

Juncus ensifolius Wikst. var. ensifolius, sword-leaved rush-occasional in WET.

Juncus ensifolius Wikst. var. montanus (Engelm.) Hitchc., dagger-leaved rush--infrequent in WET.

Juncus parryi Engelm., Parry's rush--infrequent in ROCK ( $\underline{\text { S25). }}$

Luzula campestris (L.) DC. var. multiflora (Ehrh.) Celak., manyflowered field woodrush--occasional in ABLA, ROCK, and TSME.

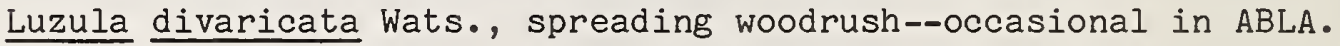

Luzula parviflora (Ehrh.) Desv., millet woodrush--infrequent in PSME, ABLA, TSME, and ABAM.

Stachys cooleyae Heller, Cooley's hedge nettle--infrequent in PIEN and ABAM.

Lathyrus lanszwertii Kell. var. aridus (Piper) Jeps., thick-leaved peavine--occasional in ROCK (S873).

Lupinus polyphyllus Lindl., Washington lupine--occasional in WET (S871).

Vicia americana Muhl. var. truncata (Nutt.) Brew., American vetch--infrequent in moist seep in ABLA, infrequent in ROCK (F2695).

Calochortus subalpinus Piper, mountain mariposa--rare in ABLA, occasional in ROCK.

Camassia leichtlinii (Baker) Wats. var. suksdorfii (Greenm.) Hitchc., Leichtlin camas--occasional in WET.

Clintonia uniflora (Schult.) Kunth., queencup beadlily-occasional in outer margins of WET; infrequent to frequent in PIEN, ABAM, TSME, and ABLA.

Disporum hookeri (Torr.) Nicholson var. oreganum (Wats.) Jones, Hooker's fairy bells--rare in ABLA. 
Erythronium grandiflorum Pursh, lambstongue fawnlily--infrequent in ROCK.

Erythronium montanum Wats., avalanche fawnlily--occasional in PIEN and PSME; infrequent in ABLA and ABAM (S848).

Lilium columbianum Hanson, Columbia or tiger lily--rare in ABLA, infrequent in ROCK.

Maianthemum dilatatum (Wood) Nels. \& Macbr., false lily-of-thevalley--infrequent on outer margins of WET.

Smilacina racemosa (L.) Desf., western Solomon's seal or false spikenard--infrequent in PIEN, occasional in shaded talus in ROCK.

Smilacina stellata (L.) Desf., starry solomonplume--frequent in ABLA; occasional in PIEN, ABAM, and TSME.

Streptopus amplexifolius (L.) DC. var. americanus Schult., claspleaf twistedstalk--occasional in PIEN and outer margin of WET.

Streptopus roseus Michx. var. curvipes (Vail) Fassett, purple twistedstalk--infrequent along outer margins of WET, infrequent in moist areas in PIEN.

Tofieldia glutinosa (Michx.) Pers. var. brevistyla Hitchc., western tofieldia--frequent to abundant in WET.

Trillium ovatum Pursh, white trillium--occasional in PIEN and ABLA; infrequent in ABAM, PSME, and TSME.

Veratrum viride Ait., American false hellebore--occasional in WET.

Xerophyllum tenax (Pursh) Nutt., common beargrass--frequent in ABLA; occasional in PIEN and TSME; infrequent in ROCK.

Lycopodiaceae

Menyanthaceae

Onagraceae
Lycopodium clavatum L., runningpine club-moss--collected in PIEN ( $\underline{\text { S } 15})$.

Menyanthes trifoliata L., buckbean--infrequent to sccasional in WET.

Epilobium alpinum L., alpine willowweed--infrequent in ROCK (2723).

Epilobium angustifolium L., fireweed--infrequent in PSME and ABLA and in rock outcrop in PIEN. 
Epilobium glandulosum Lehm. var. glandulosum, common willowweed--occasional in WET and in moist areas in PIEN (F2726).

Epilobium glandulosum Lehm. var. tenue (Trel.) Hitchc., common willowweed--infrequent in WET.

Goodyera oblongifolia Raf., rattlesnake plaintain--not sighted in 1979 but previously reported in field notes.

Habenaria dilatata (Pursh) Hook., boreal bogorchid--frequent in WET.

Habenaria saccata Greene, slender bogorchid--occasional in WET.

Listera cordata (L.) R. Br., northern listera--rare in WET.

Spiranthes romanzoffiana Cham., continental ladiestresses-infrequent in WET.

Oxalis trilliffolia Hook., great oxalis--occasional to frequent in PIEN and ABAM.

Abies amabilis (Dougl.) Forbes, Pacific silver fir--frequent to abundant in TSME, PIEN, and ABAM; occasional in ABLA.

Abies lasiocarpa (Hook.) Nutt., subalpine fir--abundant in ABLA, frequent in TSME, occasional in PIEN.

Abies procera Rehder, noble fir--frequent in PSME, infrequent in $A B L A$.

Picea engelmannii Parry ex Engelm., Engelmann spruce-occasional to frequent in PIEN.

Pinus albicaulis Engelm., whitebark pine--occasional in ABLA, TSME, and ROCK.

Pinus monticola Dougl. ex D. Don, western white pine-occasional in PIEN and ABAM; infrequent in TSME.

Pseudotsuga menziesii (Mirbel) Franco, Douglas-fir--frequent in PSME, occasional in PIEN.

Tsuga heterophylla (Raf.) Sarg., western hemlock--abundant in PSME, occasional in ABAM and PIEN.

Tsuga mertensiana (Bong.) Carr., mountain hemlock--abundant in TSME; occasional in PIEN, ABAM, and ABLA. 
Polemoniaceae

Polygonaceae

Polypodiaceae

Portulacaceae

Primulaceae

Ranunculaceae
Microsteris gracilis, (Hook.) Greene, pink annual phlox-collected in WET.

Phlox diffusa Benth. var. longistylis (Wherry) Peck, spreading phlox--occasional to frequent in ROCK.

Eriogonum compositum Dougl., northern buckwheat--infrequent in ROCK $(\underline{\mathrm{S} 875})$.

Eriogonum umbellatum Torr. var. hausknechtii (Dammer) Jones, sulfur buckwheat--occasional in ROCK (S874).

Polygonum douglasii Greene var. latifolium (Engelm.) Greene, Douglas knotweed--collected in PIEN (S807).

Rumex acetosella L., sheep sorrel--occasional in ABLA and ROCK.

Athyrium filix-femina (L.) Roth., ladyfern--infrequent in WET; occasional to frequent in moist areas in PIEN, PSME, and ABAM.

Cryptogramma crispa (L.) R. Br. ex Hook., parsley-fern-abundant in talus in ROCK.

Gymnocarpium dryopteris (L.) Newm., oakfern--occasional in PIEN.

Polystichum munitum (Kaulf.) Presl, swordfern--infrequent in PIEN and PSME.

Pteridium aquilinum (L.) Kuhn, bracken fern--rare in ABLA.

Claytonia lanceolata Pursh, lance-leaved springbeauty-infrequent in ABLA.

Montia cordifolia (Wats.) Pax \& Hoffm., broad-leaved montia-moist areas in PIEN and ABAM.

Montia sibirica (L.) Howell, western springbeauty--occa siona 1 in $A B L A, A B A M$, and PIEN.

Dodecatheon jeffreyi van Houtte, tall mountain shootingstar-occa siona 1 in WET.

Trientalis arctica Fisch., northern starflower--occasiona 1 in WET.

Actaea rubra (Ait.) Willd., baneberry--occasional in WET, PIEN, and ABAM.

Anemone oregana Gray, Oregon anemone--occasional in PIEN (S865). Aquilegia formosa Fisch., Sitka columbine--infrequent in ROCK and ABLA. 
Caltha biflora DC., twinflower marshmarigold--frequent in WET (S849).

Trautvetteria caroliniensis (Walt.) Vail., false bugbane-collected in PIEN ( S872).

Amelanchier a lnifolia Nutt., Sa skatoon serviceberry--rare in ABLA.

Fragaria virginiana Duchesne var. platypetala (Rydb.) Ha ll, broad-petaled strawberry--infrequent in PIEN and ROCK; rare in TSME.

Luetkea pectinata (Pursh) Kuntze, luetkea--abundant at base of talus slope in ROCK.

Potentilla drummondii Lehm., Drummond cinquefoil--occasional in WET (S859).

Rosa sp., rose--infrequent in $\mathrm{ABLA}$.

Rubus lasiococcus Gray, dwarf blackberry--rare in WET; infrequent to occasional in PIEN and ABAM; abundant in ABLA.

Rubus parviflorus Nutt., thimbleberry--infrequent to occasional in $A B A M$, PIEN, and PSME.

Rubus pedatus J. E. Smith, strawberry-leaf blackberry-occasional along creeks in PIEN and ABAM; infrequent in WET.

Rubus spectabilis Pursh, salmonberry--frequent in WET and in moist areas in PIEN and ABAM.

Sanguisorba occidentalis Nutt., annual burnet--rare in WET and in moist areas in PIEN.

Sanguisorba sitchensis C. A. Meyer, Sitka burnet--occasional in moist areas in PIEN and in outer margins of WET (S829).

Sorbus scopulina Greene var. cascadensis (Jones) Hitchc., Cascade mountainash--infrequent in ABLA.

Sorbus sitchensis Roemer var. grayi (Wenzig) Hitchc., Sitka or Pacific mountainash--frequent in talus in ROCK; occasional in WET, TSME, and ABLA; infrequent in PIEN and ABAM.

Spiraea densiflora Nutt., subalpine spirea--frequent in WET. Spiraea douglasii Hook., Douglas spirea--occasional in WET. 
Rubiaceae

Salicaceae

Saxifragaceae

Scrophulariaceae
Galium oreganum Britt., Oregon bedstraw--infrequent in WET, PSME, and ABLA.

Galium triflorum Michx., sweetscented bedstraw--occasional in ABAM along streams.

Populus trichocarpa T. \& G., black cottonwood--not sighted in 1979 but previously reported in field notes.

Salix pedicellaris Pursh, bog willow--abundant in WET.

Salix phylicifolia L. ssp. planifolia (Pursh) Hiitonen var. pennata (Ball) Cronq., feather-veined willow--abundant in WET.

Salix sp., willow--occasional in WET.

Mitella breweri Gray, feathery mitrewort--infrequent in moist areas in PIEN.

Mitella caulescens Nutt., leafy mitrewort--infrequent in PIEN.

Mitella pentandra Hook., fivepoint mitrewort--occasional in moist areas in PIEN.

Saxifraga arguta D. Don, brook saxifrage--infrequent along streams in PIEN.

Saxifraga bronchialis L. var. austromontana (Wieg.) Jones, matted or spotted saxifrage--occasional in ROCK.

Saxifraga oregana Howell, Oregon saxifrage--occasional in WET (S854).

Tiarella trifoliata L. var. unifoliata (Hook.) Kurtz, western coolwort--frequent to abundant in all forest types, occasional in drier portions of WET.

Castilleja miniata Dougl., scarlet paintbrush--frequent in WET, occasional in ROCK (

Castilleja suksdorfii Gray, Suksdorf's paintbrush--not sighted in 1979 but previously reported in field notes.

Mimulus guttatus DC., common monkeyflower--occasional along streams in ABAM and PIEN.

Nothochelone nemorosa (Dougl.) Straw., woodland beard-tongue-occasional on rock outcrops in PIEN, occasional to frequent in ABLA.

Pedicularis bracteosa Benth., bracted pedicularis--infrequent to occasional in WET. 


\section{Taxaceae}

Umbelliferae (Apiaceae)
Pedicularis groenlandica Retz., elephant's head pedicularis-frequent in WET.

Pedicularis racemosa Dougl., leafy lousewort--rare on rock outcrops in PIEN and PSME, occasional to frequent in ABLA.

Penstemon davidsonii Greene var. menziesii (Keck) Cronq., Davidson penstemon--occasional to frequent in ROCK.

Penstemon rupicola (Piper) Howell, cliff penstemon--occasional in ROCK.

Penstemon subserratus Pennell, fine-toothed penstemon-collected in ROCK ( $\underline{586})$.

Veronica americana Schwein., American brooklime--occasional along streams in ABAM and PIEN, infrequent in PSME.

Veronica wormskjoldii Roem. \& Schult., alpine speedwell-occasional in WET, infrequent in moist areas of PIEN and ABAM.

Taxus brevifolia Nutt., western yew--not sighted in 1979 but previously reported in field notes.

Angelica genuflexa Nutt., kneeling angelica--infrequent in WET and moist areas of PIEN.

Cicuta douglasii (DC.) Coult. \& Rose, western waterhemlock-occasional in WET.

Heracleum lanatum Michx., common cowparsnip--infrequent to occasional in WET; along creeks in PIEN, ABAM, and PSME.

Ligusticum canbyi Coult. \& Rose, Canby's lovage--frequent in WET.

Ligusticum grayi Coult. \& Rose, Gray's lovage--collected in ABLA $(\underline{S 869})$.

Lomatium martindalei Coult. \& Rose var. angustatum Coult. \& Rose, few-fruited desert parsley--frequent in ROCK.

Osmorhiza purpurea (Coult. \& Rose) Suksd., purple sweetroot-occasional in TSME, PIEN, ABAM, PSME, ABLA, and WET (S857).

Valeriana sitchensis Bong., Sitka valerian--infrequent in WET; occasional to frequent along streams in TSME, PIEN, ABAM, and PSME. 
Viola glabella Nutt., wood violet--infrequent in moist seep in ABLA.

Viola orbiculata Geyer, darkwoods vetch violet--occasional to frequent in PIEN and ABAM, infrequent in ABLA (S850).

Viola palustris L., marsh violet--frequent in moist areas in PIEN, occasional in WET (S855).

The following list includes 237 plant taxa distributed among the 47 families listed above:

\begin{tabular}{|c|c|c|c|}
\hline Family & No. of taxa & Family & No. of taxa \\
\hline Araceae & 1 & Leguminosae & 3 \\
\hline \multirow[t]{2}{*}{ Araliaceae } & 1 & Liliaceae & 16 \\
\hline & & Lycopodiaceae & 1 \\
\hline Berberidaceae & 2 & & \\
\hline Betulaceae & 1 & Menyanthaceae & 1 \\
\hline \multirow[t]{2}{*}{ Boraginaceae } & 1 & & \\
\hline & & Onagraceae & 4 \\
\hline Campanulaceae & 1 & Orchidaceae & 5 \\
\hline Caprifoliaceae & 4 & Oxalidaceae & 1 \\
\hline Caryophyllaceae & 3 & & \\
\hline Celastraceae & 1 & Pinaceae & 9 \\
\hline Compositae & 20 & Polemoniaceae & 2 \\
\hline Cornaceae & 2 & Polygonaceae & 4 \\
\hline Crassulaceae & 1 & Polypodiaceae & 5 \\
\hline Cruciferae & 1 & Portulacaceae & 3 \\
\hline Cupressaceae & 2 & Primulaceae & 2 \\
\hline \multirow[t]{2}{*}{ Cyperaceae } & 19 & & \\
\hline & & Ranunculaceae & 5 \\
\hline \multirow[t]{2}{*}{ Droseraceae } & 1 & Rosaceae & 15 \\
\hline & & Rubiaceae & 2 \\
\hline Equisetaceae & 2 & & \\
\hline \multirow[t]{2}{*}{ Ericaceae } & 22 & Salicaceae & 4 \\
\hline & & Saxifragaceae & 7 \\
\hline Gramineae & 26 & Scrophulariaceae & 12 \\
\hline \multirow[t]{2}{*}{ Grossulariaceae } & 4 & & \\
\hline & & Taxaceae & 1 \\
\hline Hydrophyllaceae & 1 & & \\
\hline Hypericaceae & 1 & Umbelliferae & 7 \\
\hline \multirow[t]{2}{*}{ Juncaceae } & 6 & Valerianaceae & 1 \\
\hline & & Violaceae & 3 \\
\hline
\end{tabular}


Acknowledgment

\section{Literature Cited}

We thank Dr. Kenton L. Chambers, Curator, Oregon State University Herbarium, and Lisa Standley, University of Washington Herbarium, who assisted with difficult identifications.

Dyrness, C. T., J. F. Franklin, C. Maser, and others.

1975. Research natural area needs in the Pacific Northwest: A contribution to land-use planning. USDA For. Serv. Gen. Tech. Rep. PNW-38, 231 p. Pac. Northwest For. and Range Exp. Stn., Portland, Oreg.

Franklin, J. F.

1966. Vegetation and soils in the subalpine forest of the southern Washington Cascade Range. Ph. D. thesis. Wash. State Univ., Pullman. $132 \mathrm{p}$.

Franklin, J. F., and C. T. Dyrness.

1973. Natural vegetation of Oregon and Washington. USDA For. Serv. Gen. Tech. Rep. PNW-8, 417 p. Pac. Northwest For. and Range Exp. Stn., Portland, Oreg.

Garrison, G. A., and J. M. Skovlin. 1976. Northwest plant names and symbols for ecosystem inventory and analysis. 4th ed. USDA For. Serv. Gen. Tech. Rep. PNW-46, 263 p. Pac. Northwest For. and Range Exp. Stn., Portland, Oreg.

Hitchcock, C. L., and A. Cronquist. 1973. Flora of the Pacific Northwest. Rev. 730 p. Univ. Wash. Press, Seattle.

Hitchcock, C. L., A. Cronquist, M. Ownbey, and J. W. Thompson. 1955-69. 5 parts. Univ. Wash. Press, Seattle. 